\title{
UNUSUAL MICA PERIDOTITES AND PYROXENITES FROM UDACHNAYA KIMBERLITE, YAKUTIA
}

\author{
SERGEY I. KOSTROVITSKY ${ }^{1}$, LIDIYA V. SOLOVJEVA ${ }^{2}$, LUYDA PH .SUVOROVA ${ }^{1} \&$ NATALY V. ALYMOVA ${ }^{1}$
}

\begin{abstract}
The petrography and the mineral chemistry of four hitherto undescribed mica xenoliths were investigated from Udachnaya kimberlite pipe. Two complex xenoliths consist of the juxtaposed pyroxenites and spinel lherzolites and contain texturally equilibrated phlogopite. ilmenite and sulfides. Their primary phlogopite has high amounts of $\mathrm{BaO}(1,7-2,25 \%), \mathrm{F}(1,45-1,6 \%), \mathrm{Cl}(0,09-0,13 \%)$, and is similar to primary mica from group A metasomatites from Udachnaya kimberlites. These samples may be interpreted as remnants of the intruded or cumulate pyroxenite series in the ancient craton lithosphere. The formation of phlogopite, ilmenitc and sulfides is thought to be due to premetamorfic mantle metasomatism. The third xenolith is a megacrystalline garnet orthopyroxenite veined with fine-grained $\mathrm{Gnt+Phl+Graph} \mathrm{aggregate} \mathrm{with} \mathrm{rare} \mathrm{clinopyroxene} \mathrm{and} \mathrm{sulfide}$ grains. Primary and secondary minerals in this xenolith are highly magnesian and close in composition to minerals from Udachnaya metasomatites $\mathrm{C}$ with reactional $\mathrm{Phl}+\mathrm{Cr}-\mathrm{Di}+\mathrm{Cr}-\mathrm{Sp}$. The rock is belived to have undergone complex history from the stage of monomineralic orthopyroxenite, possibly of magmatic nature, to the development of metasomatic Phl+Graph+Sulf, related with influx of the reducing fluids.

A fourth xenolith exhibits breccia texture and consists of porphyroclasts of common garnet lherzolites and possibly megacrystalline dunites, Porphyroclasts occur in fine-grained phlogopite-rutile-diopside-olivine groundmass with carbonates, Ti-magnetite, ilmenite, perovskite, monticellite. All minerals from porphyroclasts and groundmass are strongly heterogeneous in composition. It is likely, that fracturing and brecciation took place at the level of mantle garnet facies, and peridotite debris were cemented by a high-Ti-K melt close to protokimberlite.
\end{abstract}

Keywords: mica peridotites, pyroxenites, metasomatites, mantle breccia.

INTRODUCTION Four mica-bearing peridotites with unusual relationships between the rocks of the different composition and metasomatic minerals related to the different mantle metasomatic processes were discovered in the Udachnaya pipe. Two of them (samples $00 / 165$ and 11/84) reveal complex relationships between pyroxenites and websterites. Next one $(00 / 177)$ is a megacrystalline garnet orthopyroxenite with metasomatic phlogopite, graphite and sulfides. The fourth sample (00/93-5) is represented by the unusual mantle breccia where the porphyroclasts of anhedral olivine, pyroxenes, garnet, $\mathrm{Cr}$-spinel are cemented by a finegrained aggregate consisting of late rutile, phlogopite, clinopyroxene, olivine, Ti- magnetite, monticellite and carbonate.

\section{PETROGRAPHY Mineral definitions:}

$$
\begin{aligned}
& \text { Cpx - clinopyroxene } \\
& \text { Ol - olivine } \\
& \text { Cr-Di - Cr-diopside } \\
& \text { Opx - othopyroxene } \\
& \text { Cr-Sp - Cr-spinel } \\
& \text { Phl - phlogopite } \\
& \text { Gnt - garnet } \\
& \text { Prvs - perovskite } \\
& \text { Graph - graphite } \\
& \mathrm{Ru} \text { - rutile } \\
& \text { Ilm - ilmenite } \\
& \text { Sulf - sulfide } \\
& \text { Mont - monticellite }
\end{aligned}
$$

Two compound samples (00/165 and 11/84) contain primary (Carswell 1975) or texturally equilibrated mica (Delaney et al. 1980, Boyd et al. 1997). The first is a micabearing spinel lherzolite enriched in clinopyroxene (3-5\% Phl ; 25-35\% Ol; 15-20\% Opx; 40-50\% Cpx; <1 \% Ilm;<1 \% Sulf; $<0,5 \% \mathrm{Cr}-\mathrm{Sp})$, which include shadow xenoliths of coarse- grained orthopyroxenites $(<1 \% \mathrm{Phl} ; \sim 15 \% \mathrm{Cpx}$; $10-$ $15 \%$ Ol; $70-75 \%$ Opx; $<0,5$ Sulf). In the center of these orthopyroxene segregations the amount of $\mathrm{Ol}, \mathrm{Cpx}, \mathrm{Phl}$ abruptly decreases. The orthopyroxene grains and intergranular aggregates of $\mathrm{Ol}+\mathrm{Cpx}+\mathrm{Phl}$ from the shadow orthopyroxenites enter into neighboring lherzolite. Lherzolite has granoblastic texture with little orientation parallel to its unclear layering. The layering is marked by the enrichment of some layers in clinopyroxene and phlogopite. The mica plates $(1-2 \mathrm{~mm})$ are parallel to the foliation plane and are usually deformed. The rounded grains of sulfides (pyrrotite + pentlandite with rims of djerfisherite), ilmenite (within perovskite rims ) and fine irregular $\mathrm{Cr}$-spinel are disseminated between the silicates.

The sample 11/84 consists of juxtaposed coarse- grained mica-bearing websterite $(<1 \% \mathrm{Phl} ;<1 \%$ Sulf; $15 \% \mathrm{Cpx} ; 80-$ $85 \% \mathrm{Opx})$ and medium- grained spinel lherzolite $(<1 \% \mathrm{Cr}-\mathrm{Sp}$; $15-20 \%$ Opx; $80-85 \%$ Ol and rare fine Cpx grains). The contact between these rocks is distinct but not sharp. The grains of the both rocks enter into each other forming a granoblastic fabric. The mica plates $(1-7 \mathrm{~mm})$, grains of clinopyroxene and sulfides cement larger crystals of othopyroxene in websterite.

In general the textural and petrographic features of the 
samples $00 / 165$ and $11 / 84$ are close to that of the metamorhic metasomatites of group A form the Udachnaya pipe, where clynopyroxene, ilmenite, apatite, sulfides, graphite are found together with phlogopite (Solovjeva et al.1997). As a rule, the metosomatic minerals in such rocks are texturally and chemically equilibrated with the primary minerals and often show spatial relationships with the pyroxenites (Solovjeva et

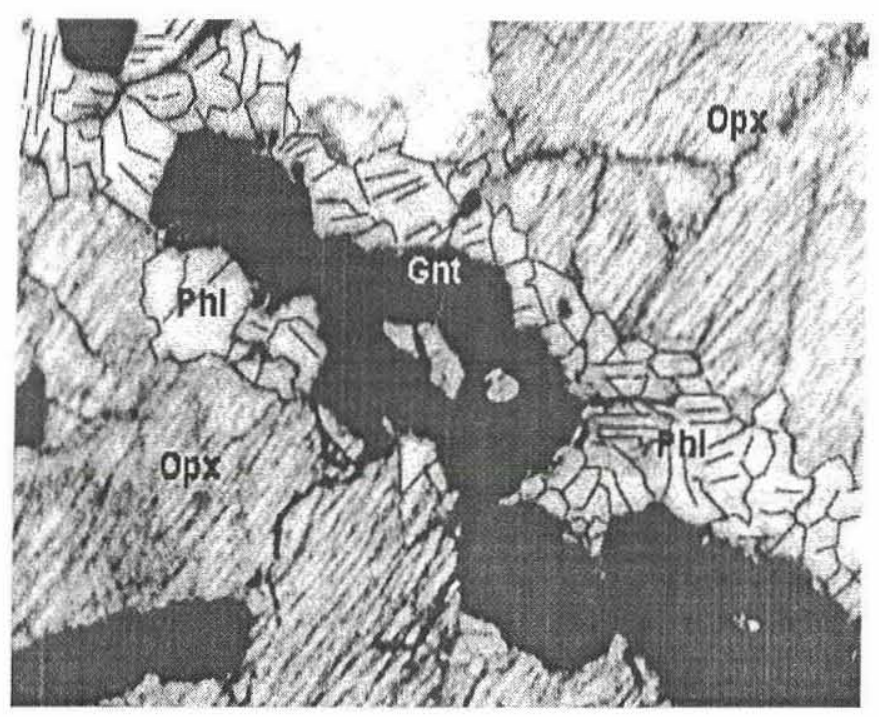

Figure I - Garnet veinlet with fine-grained phlogopite rims, which cross orthopyroxene megacryst. Garnet relics (light) are surrounded with black kelyphite. PPL, magnification' 40; sample 00/I77.

\section{al. 1994).}

The sample $00 / 177$ is represented by the megacystalline garnet orthopyroxenite with graphite, phlogopite and sulfides ( 1\% Graph; 10-12\% Phl; 5-7 \% Gnt; 3-5 \% Ol; 80\% Opx; single Cpx grains). Opx megacrysts $(2-5 \mathrm{~cm})$ are deformed and broken at the margins into the separate blocks, veined by garnet, phlogopite, graphite with the rare grains of clinopyroxene and sulfides. Megacrysts are cut of the veinlets, filled by Gnt + Phl + Graph (Fig. 1).

The puzzle of this rock is some well faceted olivine crystals and rare small regular garnet crystals, that may attest to the free growth conditions in fluid or melt (?) during the formation of intergranular aggregate. Graphite form two generations: 1) fine $(<0,05 \mathrm{~mm})$ laths, located near the thin $\mathrm{Gnt}+\mathrm{Phl}$ veinlets within the Opx megacrysts; 2) larger $(0,5-3 \mathrm{~mm})$ flakes, located in the intergranular space, where hexagonal prisms with rounded planes and edges and the shapes similar to dipyramids and octahedrons are together with the irregular graphite grains. The hatching according to the prism and the triangle growth sculptures are obviously displayed on the pinacoids. Carbon isotope compositions of graphite were obtained at the Geochemistry Institute, Moscow via massspectrometer DELTA-plus, using standard techniques. Large graphite flakes $C_{1}$ from the intergranular aggregate show a value $\delta^{13} \mathrm{C}=-5.1 \pm 0.1 \%$ while small graphite laths in

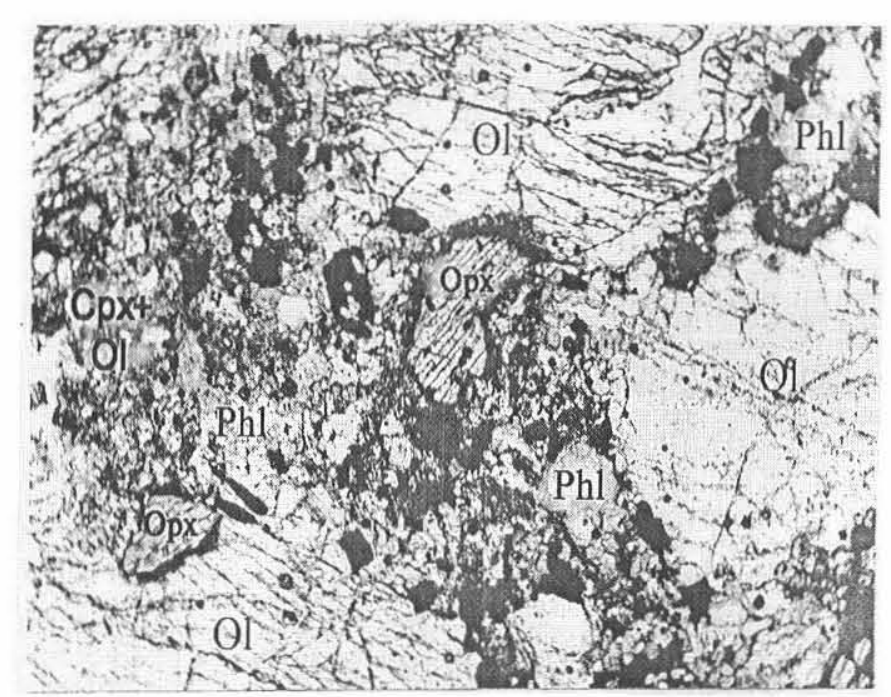

Figure 2 - Relationship of mineral debris (light) and finegrained cement in the sample 00/93-5. There are large olivine porphyroclasts, in the center there is an orthopyroxene fragment with thin reactional rim from late-metasonatic minerals. The black small prismatic grains are rutiles, which are almost entirely replaced by ilmenite and perovskite. PPL, magnification' 60 .

orthopyroxene megacrysts $\mathrm{C}_{2}$ are isotopically lighter $(-5.8 \pm$ $0.1 \%$ ). Both values lie within the $\delta^{1.3} \mathrm{C}$ range for P-type diamonds from the Udachnaya pipe and coincide with isotopic composition of the carbon from the homogenous mantle source (Galimov 1991).

The sample 00/93-5 is the "mantle breccia". The rock has a brecciated texture and in $65-70 \%$ consists of rounded and subangular mineral debris of olivine (3-15 mm), orthopyroxene $(1-3 \mathrm{~mm})$ and rare garnet $(4 \mathrm{~mm})$ immersed in the fine-grained (0.05-0.2 mm) olivine-clinopyroxene-phlogopite cement with rutile, ilmenite, monticellite and other minerals (Fig. 2).

Rare garnet with the kelyphitic rims, clinopyroxene and $\mathrm{Cr}$ spinel grains occur as fine fragments. Fine well shaped clinopyroxene crystals, rounded garnel grains and single grains of orthopyroxene occur as inclusions in olivine porphyroclasts. Approximate modal compositions of fragments larger than $0.5 \mathrm{~mm}$ is: $~ 80 \% \mathrm{Ol}$; $15-20 \% \mathrm{Opx} ; \sim 1 \% \mathrm{Gnt}+$ $\mathrm{Cpx}+\mathrm{Cr}-\mathrm{Sp}$. The modal composition of the fine-grained matrix is the following: $30-40 \% \mathrm{Phl} ; 25-30 \% \mathrm{Cpx} ; 20-30 \%$ Ol; 3-5 \% Mont; 10-15\% Ru, nearly entirely substituted by Prvs and Ilm; 1-3\% of Ti-magnetite and $\sim 1 \%$ of carbonates.

Olivine in the groundmass is represented by fine rounded grains and euhedral crystals. Phlogopite forms regular-shaped plates with narrow strongly pleochroic rims. Prismatic rutile grains are altered to fine-grained ilmenite-perovskite aggregate. Small sulfides tracing the fractures are likely to represent djerfisherite.

According to the mineral inclusions in olivine porphyroclasts it is possible to suggest that brecciated rocks were megacrystalline dunites or lherzolites, which are common among the Udachnaya xenolith population (Sobolev et al., 1984; Solovjeva et al., 1994). According to the cement 
composition the described mantle breccia is close to the "polymict peridotites" from the Bultfontein and De Beers kimberlitie pipes, South Africa (Lawless et al ., 1979). All studied peridotite samples, except for the essentially serpentinized xenolith $11 / 84$, are fresh.

MINERAL CHEMISTRY The minerals of the compound samples $(00 / 165$ and $11 / 84)$ in general are close in composition to those from pyroxenites and lherzolites with texturally equilibrated mica (group A, after Solovjeva et al.1997).

Olivine is represented by the forsterite with $\mathrm{mg} \#=0,925 \mathrm{in}$ the both samples. The concentration of $\mathrm{CaO}, \mathrm{Al}_{2} \mathrm{O}_{3}, \mathrm{Cr}_{2} \mathrm{O}_{3}$ and $\mathrm{TiO}_{2}$ are below detection limit. A sharp zonation was found in the narrow rims $(50-150 \mathrm{~m} \mu)$ of olivine grains from the sample $00 / 165(10,4 \mathrm{Fa}$ in rim comparing with 7,3 in the center of the

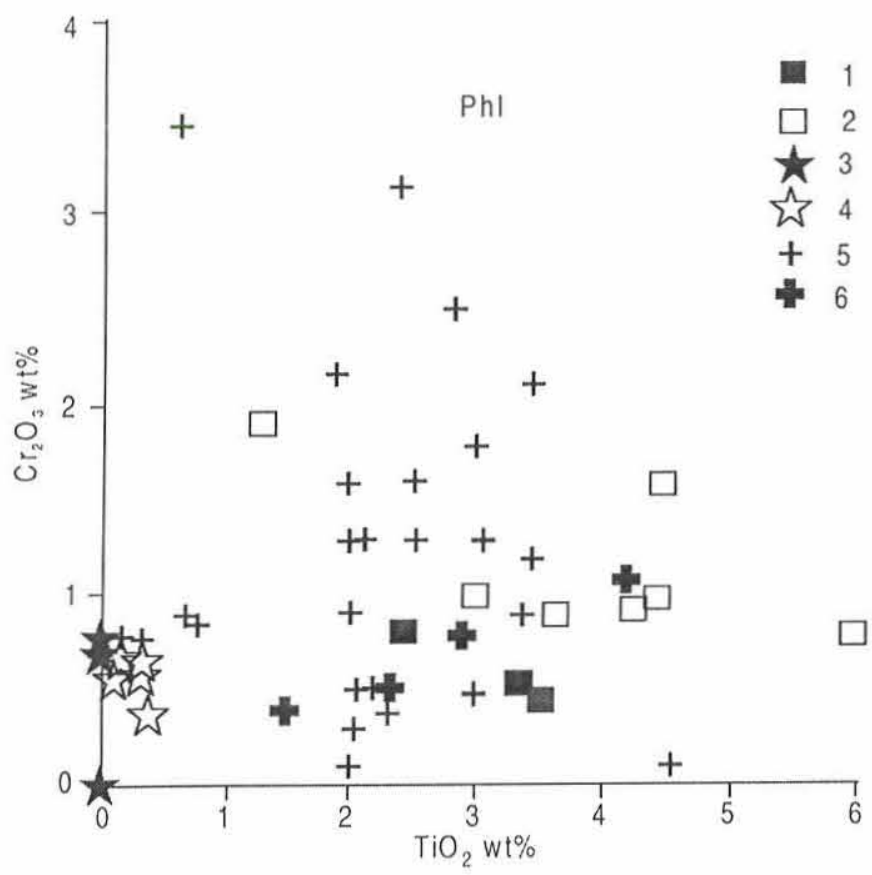

Figure 3 - Plot of $\mathrm{Cr}_{2} \mathrm{O}_{3}$ versus $\mathrm{TiO}_{2}$ in phlogopite from different types mica xenoliths from Udachnaya kimberlite. (I) - compound pyroxenite-lherzolite xenoliths with texturally equilibrated mica, samples 00/I65 and II/84. (2) - mica peridotite, pyroxenite with texturally equilibrated mica (Group A), (Solovjeva et al. 1997). (3) - graphite-bearing garnet orthopyroxenite with phlogopite and sulfide, sample 00/177. (4) rocks with reactionary association $\mathrm{Phl}+\mathrm{Cr}-\mathrm{Di}+\mathrm{Cr}-\mathrm{Sp}$ (group C), (Solovjeva et al. 1997). (5) - secondary mica from peridotites and eclogites (Solovjeva et al., 1997). (6) - mantle breccia 00/93-5.

grain ).

Orthopyroxene is represented by enstatite: $\mathrm{mg} \mathrm{\#}=0,927$ 0,$932 ; 2,8-3,3 \% \mathrm{Al}_{2} \mathrm{O}_{3} ; 0,24-0,46 \% \mathrm{CaO}$.

Clinopyroxene is a Ca-diopside with $\mathrm{Ca} /(\mathrm{Ca}+\mathrm{Mg})$ at. = 0,478-0,507 (0,0-0,28\% $\mathrm{TiO}_{2} ; 0,95-1,25 \% \mathrm{Cr}_{2} \mathrm{O}_{3} ; 3,4-4,4 \%$
$\left.\mathrm{Al}_{2} \mathrm{O}_{3} ; 1,4-1,7 \% \mathrm{Na}_{2} \mathrm{O}\right)$.

$\mathrm{Cr}$-spinel from the sample $00 / 165$ contain $39 \% \mathrm{Al}_{2} \mathrm{O}_{3} ; 27 \%$ $\mathrm{Cr}_{2} \mathrm{O}_{3} ; 17 \% \mathrm{MgO}$ and essential admixture of $\mathrm{Fe}^{3+}\left(\mathrm{Fe}^{3+} /\right.$ $\left(\mathrm{Fe}^{2+3+}+\mathrm{Fe}^{2+}\right)$ at. $\left.=0,24\right)$.

Phlogopite has a high $\mathrm{mg} \#=0,939-0,953$ and high content of $\mathrm{BaO}, \mathrm{F}$ and $\mathrm{Cl}(1,7-2,25 \% \mathrm{BaO} ; 1,45-1,6 \% \mathrm{~F} ; 0,09-0,13 \%$ $\mathrm{Cl})$, with the evident decrease of the amounts of two first in the narrow marginal zones. The phlogopites from the samples 00/ 165 and $11 / 84$ are grouped on the diagram $\mathrm{TiO}_{2}-\mathrm{Cr}_{2} \mathrm{O}_{3}$ to the left and a few below the points of the texturally equilibrated phlogopite from the rocks of the group A (Fig. 3).

A temperature, calculated using the geothermometer of Finnerty and Boyd (1987), in the sample 00/165 is estimated as $835^{\circ} \mathrm{C}$.

The anhedral olivine grains in the sample $00 / 177$ have homogeneous composition $(\mathrm{mg} \#=0.915)$. The sharp zonation is found in euhedral olivine grain (center - 8,4 Fa and 4,4 Fa in the narrow rims). The outer magnesian rim usually overgrows on the primary olivine without the transitional zones but sometimes intermediate compositions are registered $(6,7 \mathrm{Fa})$.

Garnet composition is characterized by high and varying $\mathrm{Cr}_{2} \mathrm{O}_{3}(6,7-7,4 \%), \mathrm{CaO}(4,5-5,8 \%)$ contents and lack of $\mathrm{TiO}_{2}$.

Clinopyroxene forms small fresh patches in strongly altered grain $\left(\mathrm{Ca} /(\mathrm{Ca}+\mathrm{Mg})\right.$ at. $\left.=0.464 ; 0,38 \% \mathrm{TiO}_{2} ; 0,57 \% \mathrm{Cr}_{2} \mathrm{O}_{3}\right)$ and is probably closer to the primary composition.

Phlogopite reveal low $\mathrm{Cr}_{2} \mathrm{O}_{3}$ content $(0.75 \%)$, lack of $\mathrm{TiO}_{2}$ and small amounts of $\mathrm{BaO}\left(0,0^{-}-0,3 \%\right), \mathrm{F}(0,0-1,4 \%)$, and $\mathrm{CI}$ $(0,0-0,14 \%)$. Points of phlogopites from the sample $00 / 177$ plot within the field of mantle metasomatites from Udachnaya pipe, with the reactional association $\mathrm{Phl}+\mathrm{Cr}-\mathrm{Di}+\mathrm{Cr}-\mathrm{Sp}$ (group C, Solovjeva et al. 1997) - Fig. 3.

$\mathrm{Cr}$-Spinel from the intergranular aggregate vary chemically from high- $\mathrm{Cr}-$ spinel $(\mathrm{Cr} /(\mathrm{Cr}+\mathrm{Al})$ at. $=0,81)$ to common spinel $(\mathrm{Cr} /(\mathrm{Cr}+\mathrm{Al})$ at. $=0,20)$.

In general all minerals from this sample are close in composition to the respective minerals from the metasomatic group $\mathrm{C}$ from Udachnaya pipe. The only exception is the low $\mathrm{Cr}_{2} \mathrm{O}_{3}$ concentration in clinopyroxene what is probably explained by later modification.

The compositions of the coexisting olivine and $\mathrm{Cr}$ - spinels from the different paragenetic groups including those containing graphite and diamond are shown in figure 4.

The central part of the zoned olivine from the sample 00/ 177 locates slightly to the left of the field of reactional metasomatites of $\mathrm{C}$ group. The intermediate composition drops near the two points of the graphite peridotites, and the magnesian rim on the euhedral crystal is near the points of the ultra-depleted peridotites from Lesotho kimberlites (Carswell et al. 1979).

As a whole, the similarity of mineral compositions from the sample 00/177 and metasomatites $C$ from Udachaya pipe with mineral compositions from graphite and diamond paragenesis doesn't exclude community of processes in their formation. T and $\mathrm{P}$ of primary paragenesis in the sample $00 / 177$, calculated using thermobarometer of Finnerty, Boyd (1987), are estimated as $950^{\circ} \mathrm{C}$ and $48.5 \mathrm{~kb}$.

Minerals of primary fragmentary paragenesis in the sample 00/93-5 (mantle breccia) are highly magnesian (mg\#: Ol 0,921; Opx - 0,935; Cpx - 0,934; Gnt - 0,817). 


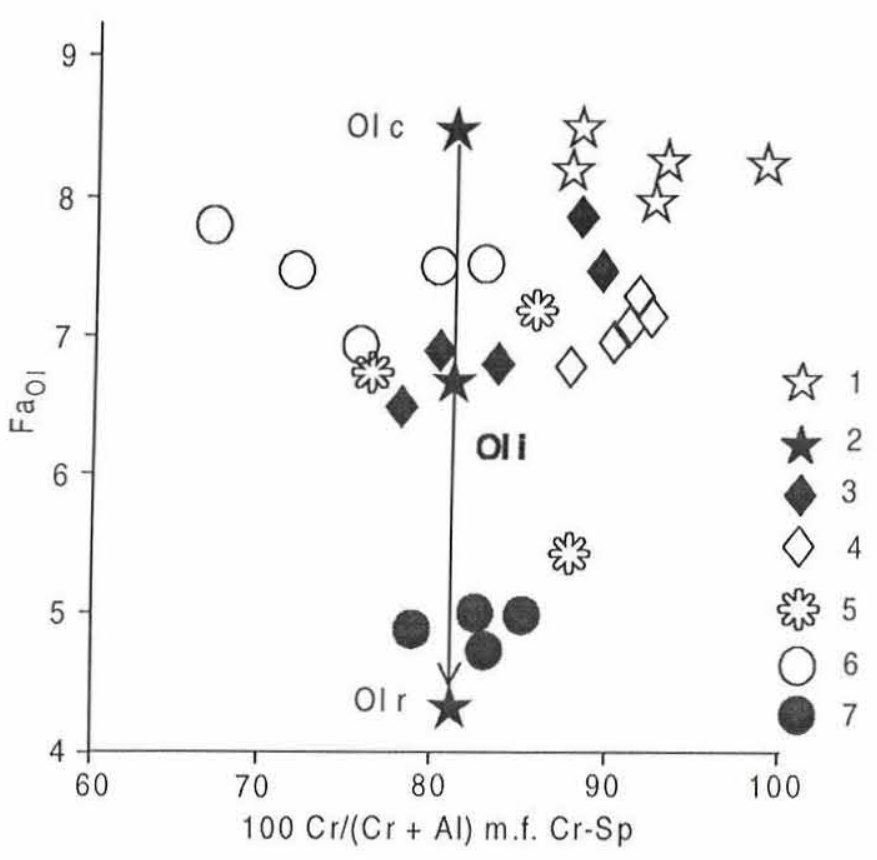

Figure 4 - Plot of $\mathrm{Fa}$ in olivines $\left(\mathrm{Fa}_{\mathrm{ol}}\right)$ versus $100 \mathrm{Cr} /(\mathrm{Cr}+\mathrm{Al})$ at. in Cr-spinel. (I) - reactionary $\mathrm{Phl}+\mathrm{Cr}-\mathrm{Di}+\mathrm{Cr}-\mathrm{Sp}$ metasomatic aggregates (group $C$ ) in xenoliths from Udachnaya pipe and 200 pipe, Lesotho (Solovjeva et al. 1997). (2) - graphite-bearing garnet orthopyroxenite 00/I77: $\mathrm{Ol}_{c}$ center of zoning crystal; $\mathrm{Ol}_{r}$ - thin rim; $\mathrm{Ol}_{i}$ - intermediate composition of Ol grain from this sample. (3) - graphite therzolites, harzburgites from Udachnaya pipe (Solovjeva et al. 1997) and Lesotho pipes (Boyd, Nixon 1975). (4) diamond-bearing harzburgite-dunites from Udachnaya pipe (Sobolev et al. 1984). (5) - combined olivine and chromite inclusions in diamond (Daniels et al., 1991, Gurney et al. 1984). (6) - chromite-garnet lherzolites from 200 pipe, Lesotho (Carswell et al., 1979). (8) - ultra-depleted chromite harzburgites and lherzolite from 200 pipe, Lesotho (Carswell et al. 1979).

Garnet is Cr-pyrope of therzolite type $\left(6,8 \% \mathrm{Cr}_{2} \mathrm{O}_{3} ; 6,0 \%\right.$ $\mathrm{CaO})$, and clinopyroxene is $\mathrm{Cr}$-disposide $\left(2,9 \% \mathrm{Cr}_{2} \mathrm{O}_{3}\right)$ with low $\mathrm{Ca} /(\mathrm{Ca}+\mathrm{Mg})$ at. $(0,476)$.

$\mathrm{Cr}$-spinel from porphyroclasts is weakly oxidized and has high $\mathrm{Cr} /(\mathrm{Cr}+\mathrm{Al})$ at. $(0,66)$.

In general, mineral compositions of porphyroclasts correspond to those of garnet lherzolites and partly megacrystlline dunites from Udachaya pipe (Solojeva et al.1994, Boyd et al.1997, Sobolev et al. 1984).

Practically all minerals of primary paragenesis were subjected to reactional action of fluid or melt, which formed the breccia cement. Small olivine clasts have higher Fe content ( $m g \#=0,882)$ than large ones $(0,921)$. Newly formed euhedral olivine crystals are sharply zoned $(\mathrm{mg \#}=0,889$ in the center and 0,929 in the rim). Orthopyroxene porphyroclasts reveal decrease in $\mathrm{mg} \#$ and increase in $\mathrm{TiO}_{2}, \mathrm{CaO}, \mathrm{Na}_{2} \mathrm{O}$ contents in the rims.

$\mathrm{T}$ and $\mathrm{P}$ for conventional primary paragenesis, calculated using the thermometer of Finnerty \& Boyd (1987), are estimated as $838^{\circ} \mathrm{C}$ and $37 \mathrm{~kb}$.

Minerals from breccia cement are clearly heterogeneous and their chemistry is comparable to "MARID" minerals from Udachaya pipe, South Africa pipes and cement minerals of "polymict peridotites" from Bultfontein and De Beers pipes, South Africa (Solovjeva et al., 1994; Lawless et al. 1979).

Clinopyroxene from breccia cement is low- $\mathrm{Al}$ and low-Na diopside with $\mathrm{Ca} /(\mathrm{Ca}+\mathrm{Mg})$ at. $=0,511$.

Chemically heterogeneous phlogopite plates reveal variations in $\mathrm{TiO}_{2}$ and $\mathrm{Cr}_{2} \mathrm{O}_{3}$ contents $(1,5-4,17 \%$ and $0,37-$ 1,09\%). In Figure 3 points of phlogopite from breccia cement reveal direct correlation between $\mathrm{Cr}_{2} \mathrm{O}_{3}$ and $\mathrm{TiO}_{2}$ contents and are located within the field of secondary micas, as well as partly within the field of rocks with texturally equilibrated mica. Chemically phlogopite from mantle breccia is close to "MARID" mica (Dawson \& Smith 1977, Solovjeva et al.1994).

Rutile from breccia has visible admixture of $\mathrm{Cr}_{2} \mathrm{O}_{3}(1,77 \%)$ and $\mathrm{FeO}(1,8 \%)$ and its composition is comparable with "MARID" rutile from South Africa kimberlite (Dawson \& Smith 1977).

Ilmenite varies chemically in $\mathrm{TiO}_{2}(32,1-53,7 \%), \mathrm{FeO}$ $(25,5-29 \%), \mathrm{MgO}(11,7-13,4 \%), \mathrm{Fe}^{3+} /\left(\mathrm{Fe}^{3+}+\mathrm{Fe}^{2+}\right)$ at $=0,12^{10 t}$ 0,78. Composition heterogeneity is also fixed in Ti-magnetite and monticellite.

Small carbonate grains in breccia cement are represented by calcite and dolomite. Composition heterogeneity of matrix minerals, zoned reactional rims on primary minerals, variation of ferric iron in ilmenite and Ti- magnetite from breccia cement are evidence of nonequilibrium conditions of crystallization, and as seems, of changing oxidizing state.

NATURE OF THE STUDIED SAMPLES The petrography of the studied samples (00/165, 11/84) and rocks of group A with the texturally equilibrated mica from the Udachnaya pipe displays the common relation of mica with pyroxenites and websterites. This association is evident also when mica forms separate plates, veinlets or phlogopite clinopyroxene bands in granular garnet and spinel peridotites. The rare deformed sulfide globules may suggest the original magmatic nature of pyroxenites and websterites. The contact between the mica websterite and spinel lherzolite in the sample 11/84 may testify both the premetamorphic intrusion of websterite dyke or sill into lherzolite and the adjoining of different cumulate layers. The shadow xenoliths of pyroxenites within the lherzolite in the sample 00/165 may represent metamorphosed relics of early dyke or crystal cumulates. The peculiarities of the REE distribution in pyroxenites and websterites (with the signs of the primary cumulative genesis) from the Udachnaya pipe are not in the contradiction with the hypothesis of their origin from the komatiite, basalt -komatiite and basalt melts (Solovjeva et al. 2000). The appearance of phlogopite, ilmenite and sulfides is supposed due to a premetamorphic metasomatism.

The evolution of the sample $00 / 177$ with metasomatic graphite, phlogopite, sulfides possibly proceeded in two or tree stages. The megacrystalline othopyroxene rock is thought to be 
of the original cumulate genesis. Megacrystalline orthopyroxenites with intergranular veinlets of garnet and minor clinopyroxenes are common in the xenolith population of the Udachnaya pipe. The peculiarities of these rocks evidence the recrystallization of exsolved garnet and clinopyroxene from primary homogeneous pyroxene into the intergranular aggregate under the conditions of cooling and high pressure.

The later association of $\mathrm{Phl}+\mathrm{Graph}+$ Sulf is probably related with the influx of the fluids. The heterogeneity of OI, $\mathrm{Gnt}, \mathrm{Phl}$ composition shows the lack of complete equilibration of minerals in the rock and the development of metasomatic association not far before the kimberlite formation. The sharp increase of $\mathrm{mg} \#$ in the marginal parts of olivine, high $\mathrm{Cr}$ content in garnet and spinel and the development of graphite do not provide evidence against the high reducing state of the fluids, as was shown for the reactional metasomatites of group C (Solovejeva et al. 1997). Some morphological features of graphite possibly suggest its paramorphic origin after the primary diamond. It is not excluded that some part of the carbon was dissolved in the primary pyroxene and then was exsolved in the period of the general metamorphism. Later during the metasomatic stage the graphite crystals were enlarged being in the equilibrium with the passing reducing fluid. Thus, we can assume that a lighter carbon in graphite $\mathrm{C}_{2}$ indicates an incomplete equilibrium between the carbon supplied by the fluid $\left(\mathrm{C}_{1}\right)$ and a lighter primary carbon of the rock.

The nature of the mantle breccia may be discussed according to the composition of the fragmental material and the cementing fine-grained matrix. The fragmental material in rough estimate of the modal composition refers to the Iherzolites or harzburgites. Primary compositions of their minerals relate to garnet lherzolites or megacristalline dunites from Udachnaya pipe (Sobolev et al. 1984, Solovjeva et al. 1994). Some textural features, namely the inclusions of well shaped crystals of clinopyroxene and rounded grains of garnet in large olivine porphyroclasts, evidence the presence of megacrystalline dunites debris in breccia. It is likely that both types of rocks underwent fracturing and brecciation in the mantle and the process of the fragmentation took place at the level of the garnet facies. Unlike mantle breccia from the Udachnaya pipe, the "polymict peridotites" from Bultfontein and De Beers (Lawaless et al. 1979) contain eclogite and megacryst fragments. P. Lawaless et al. (1979) consider the "polymict peridotites" to be the conduits remnants of kimberlite melts passed through the lithospheric mantle. The cement of the mantle breccia was possibly created after the crystallizaion of the high- $\mathrm{Ti}-\mathrm{K}$ melt containing carbon dioxide and $\mathrm{F}$.

MAIN CONCLUSIONS 1-Compound samples 00/165 and 11/84 with the contacts between granular peridotites and pyroxenites and containing texturally equilibrated mica reflect the existence of the intruded or cumulate pyroxenite within the ancient craton lithosphere. The origin of phlogopite, ilmenite and sulfides is thought to be due to premetamorfic mantle metasomatism.

2 - Graphite-bearing garnet orthopyroxenite with phlogopite and sulfides (sample 00/177) reveals two major episods of their evolution. The earlier stage was related to the existence of monomineralic orthopyroxene rock possibly of magmatic nature similar to pyroxenites from the samples $00 / 165$ and $11 /$ 84. In the period of general metamorphism the rock underwent recrystallization due to the cooling. The formation of $\mathrm{Phl}+$ Graph + Sulf is possibly related to influx of reducing fluids just before kimberlite formation.

3 - Mantle breccia (sample 00/93-5) was formed during the fracturing of the rocks similar to garnet lherzolites of the common type and megacrystalline dunites. The matrix of breccia was formed by crystallization of a high - Ti, K melt like that of protokimberlites.

Acknowledgements The investigations were supported by RFBR (grant N 02-05-64793). To the reviewers of RBG for the suggestions to the manuscript.

\section{References}

Boyd F.R.. Nixon P.H. 1975. Origins of the ultramafic nodules from some kimberlites of Northern Lesotho and Monastery mine, South Africa. Phys. Chem. Earth, 9: 431-454.

Boyd F.R., Pokhilenko N.P., Pearson D.G., Mertzman S.A.et al. 1997. Composition of the Siberian cratonic mantle: evidence from Udachnaya peridotite xenoliths. Cont. Miner. Petrol., 128: 228-246.

Carswell D.A. 1975. Primary and secondary phlogopites and clinopyroxenes in garnet therzolite xenoliths.. Phys. Chem. Earth, 9: 417-430.

Carswell et al. 1979. The petrology and geochemistry of ultramafic nodules from pipe 200, Northern Lesotho. The mantle sample: inclusions in kimberlites and other volcanics. AGU Washington D.C.: 127-144.

Daniels L. R. et al. 1991. Oxygen fugacity constrains on the Southern African lithosphere. Cont. Miner. Petrol., 108:154.

Dawson J. B., Smith J. V. 1977. The marid (mica- amphibole- rutile- ilmenitediopside) suite of xenoliths in kimberlite. Geochim. Cosmochim. Acta, 41:309-323.

Delaney J.S. et al. 1980. Chemistry of micas from kimberlites and xenoliths- II. Primary- and secondary- textured micas from peridotite xenoliths. Geochim.
Cosmochim. Acta, 44: 857 - 872 .

Finnerty A.A., Boyd F.R. 1987. Thermobarometry for garnet peridotites: basis for determination of thermal and compositional structure of the upper mantle. In: P.H.Nixon, ed., Mantle xenoliths. John Wiley and Sons, pp.: 381-4()2.

Galimov E. M. 1991. Isotope fractionation related to kimberlite magmatism and diamond formation. Geochim. Cosmochim. Acta, 55:1697-1708.

Gurney J.J. et al. 1984. Mineral associated with diamonds from the Roberts Victor mine. In: Kimberlites II: The mantle and crust- mantle relationships, Servier, рр.: 25-32.

Lawless P.J. et al. 1979. Polymict peridotites from the Bultfontein and De Beers mines, Kimberley, South Africa .In: The mantle samples:inclusions in kimberlites and other volcanics, 2:145-155.

Sobolev N. V. et al. 1984. Diamond- bearing peridotite xenoliths in kimberlites and the problem of the origin of diamonds. Geologiya and Geofizika (Russian Geology and Geophysics), 12: 63-80.

Solovjeva L.V. et al. 1994. Kimberlites and Kimberlite- like rocks. The Substance of the upper Mantle beneath ancient Platforms [in Russian].Novosibirsk: 255 . 
Solovjeva L.V. et al. 1997. Mantle metasomatism and melting in mantle-derived xenoliths from the Udachnaya kimberlite; their possible relationship with diamond and kimberlite formation. Rissian geology and geophysics, 38(1):182-204

Solovjeva L.V., Gornova M.A., Lozhkin V.I. 2000. Rare earths in xenoliths of pyroxenites, eclogites and basic granulites from kimberlite pipes Udachnaya and Obnazhennaya, Yakutia. Dokladi RAN, V. 373(4):532 - 535.

Manuscrito A-130

Recebido em 22 de novembro de 2001 Revisão dos autores em 18 de dezembro de 200 Revisão aceita $\mathrm{em} 19$ de dezembro de 2001 